\title{
Flight to Light Response of Red Pumpkin Beetle (Aulacophora africana Weise) to Differently Coloured Light-emitting Diode and Incandescent Bulb Lights
}

\author{
Alexander Timothy Chukwu*, Nuhu Samaila, Emmanuel Okrikata** \\ Department of Biological Sciences, Faculty of Pure and Applied Sciences, Federal University Wukari, \\ Taraba State, Nigeria.
}

\section{Corresponding Author email: \\ * alexchukwu72@gmail.com \\ ** okrikata@yahoo.com}

Article History

Received: 14 October 2019

Revised: 03 November 2019

Accepted: 24 November 2019

Published: 25 November 2019

Student(s)

- $\quad$ Alexander Timothy Chukwu

- Nuhu Samaila

Academic Year: 2018-19 (2 ${ }^{\text {nd }}$ Semester)

Course Level: Bachelor

Course Name: B.Sc. (Biology)

Course year: $4^{\text {th }}$ Year $/ 8^{\text {th }}$ Semester

$\operatorname{Mentar}(\mathrm{s})$

- Emmanuel Okrikata

\section{A BSTRACT}

Red pumpkin beetle (Aulacophora africana Weise) is an important defoliator and vector of pathogens to its numerous crop hosts. Control had largely been by synthetic insecticides with their attendant consequences on man and the environment thus necessitating scientific studies on environmental-friendly management strategies. The experiment was conducted in the Research Farm of Federal University Wukari in the month of May 2019 with the aim of evaluating the attractiveness of $A$. africana to Light-emitting diode (LED) and Incandescent Light bulb colours. Five colours (red, yellow, green, blue and white) were used for the study. Each colour light was properly projected on 2 metre vertical screen (made of white polyethene) placed one meter above the ground. A setup without bulb served as the control. The light traps were arranged in a completely randomized design (CRD) in 6 replicates and ran simultaneously for six hours (1800 to $2400 \mathrm{hrs}$ ). The pumpkin beetles attracted were collected in tubs containing soapy water. A. africana collected were counted and recorded according to bulb type and colour. Samples were identified at the Insect Museum of Ahmadu Bello University, Zaria. Among the Incandescent bulbs, White colour was most attractive to $A$. africana $(4.30 \pm 0.38)$ while red attracted the least $(0.71 \pm 0.01)$. Among LED bulbs, Blue was most attractive (3.99 \pm 1.01$)$ while Red also attracted the least $(0.78 \pm 0.03)$. Overall, LED attracted more pumpkin beetles than Incandescent bulb even though Student Newman Keul's test indicates that the difference between them was due to random variation $(\mathrm{p}=0.16)$. Correlation and regression analyses indicated increase in insect attraction with increased light intensity. The results therefore suggest that white Incandescent or blue LED bulb colours can be incorporated into insecticidal light traps to suppress their population/attract them away from host plants or fixed into ordinary light traps to harvest the insect for scientific studies.

Keywords: Attractiveness, Incandescent, Light bulb colours, Light-emitting diode, Red pumpkin beetle (Aulacophora africana Weise). 


\section{Introduction}

Despite the vital ecosystem services insects provides, many species are pestiferous, causing substantial damage to agriculture and agricultural produce. They also vector various pathogens of plants and animals [1]. One of such noxious insects is the Red pumpkin beetle (Aulacophora africana Weise). Red pumpkin beetle is a polyphagous insect, capable of attacking more than 81 plant species such as cucumber, pumpkin, bottle gourd, squash, snake gourd, watermelon, among others. It is one of the most noxious pests of cucurbits, with the adult beetle feeding voraciously on leaves, flowers and buds, while the larval stage feeds on root tissues of seedlings, thus capable of causing up to $30-100 \%$ yield loss [2]. The damage caused by red pumpkin beetle has been reported to be severe as the pest persists throughout the year, hence usually difficult to control [3]. Aside synthetic chemical insecticides, different other control measures used on red pumpkin beetle have been documented with minimal results. Datinon [4] reported inadequate knowledge of control of red pumpkin beetle among Jatropha curcas farmers in Benin, Rashid [2] reported methods such as ploughing and planking operations, application of wood dust, tobacco dust (snuff), kerosene oil, wood ash, road dust, cow dung ash, spray of water and spray of chemicals while the use of resistant cucumber variety was reported by Bidein [5] with little effect on the intensity of red pumpkin beetle infestation. Of interest is that the use of synthetic pesticides has been the most effective control measure used against red pumpkin beetles. However, indiscriminate use of these insecticides is not without its adverse effect on both humans and the environment [6]. Hence the needs for an environmentally friendly and effective pest control measure such as insecticidal light trap.

Artificial light sources have been reported to influence insect behaviours in various ways as insects have been found to show preference to specific light colours and sources [7]. For instance, ultraviolet (UV) light and blue coloured light have been reported as more attractive to most insects than do other wavelengths [8], [9]. Hence in recent years, considerable interest is being focused on pest management strategies that utilizes the responses of insects to light as a "clean" form of pest control that does not use synthetic insecticides [9], [10].

\section{Impact of Artificial Light on Nocturnal Insects}

More than 60\% invertebrates, red pumpkin beetles inclusive, are reported to be nocturnal, hence exhibits phototaxis [11]. Also, the flight-to-light response of insects has largely been attributed to the source, wavelength and intensity of the artificial light which interferes with the natural moon light used as cue by the insects at night [9]. Although the phototactic response of nocturnal insect to artificial light are not without its negative impact on the ecosystem and insect diversity as it makes the species more vulnerable [11], inhibits a lot of bio-processes [12] among others, artificial light have been used in insect traps to study insect population dynamics and diversity, sample population of pest species, delimitate infested areas, among others [13].

Most research on the attractiveness of insects to artificial light have been on temperate environment and only few have evaluated their responses at species level [14]. Thus, considering that red pumpkin beetle is largely nocturnal, the present study investigated the bulb light colour and type which is most attractive to the insect with the aim of providing such basic information which could be instrumental in its integrated pest management strategies and/or used to harvest the species for scientific studies.

\section{Materials and Methods}

\subsection{Study area}

The experiment was carried out in the Research Farm of Federal University Wukari, Taraba State, Nigeria. Wukari has an elevation of $187 \mathrm{~m}$ above sea level, a mean annual temperature of $26.8^{\circ} \mathrm{C}$ and a mean annual rainfall of $1205 \mathrm{~mm}$. It experiences a warm tropical climate characterized by dry and wet seasons. The wet season commences in April and terminates in October with peak periods in June and September. 


\subsection{Insect sampling technique}

The experiment was carried out in May 2019. As shown in Figure 1, fabricated light traps were used as the sampling instruments. The traps were constructed using white polyethylene sheetings (served as a screen) which were attached to two wooden poles at $1 \mathrm{~m}$ above ground level and a collecting tub containing soapy water was placed under the traps. A total of 12 traps were constructed; 5 traps had differently coloured (Red, Yellow, Green, Blue and White) light-emitting diode [LED] bulbs (ECOMIN-QP05014/3W; AC220$240 \mathrm{~V} / 50-60 \mathrm{~Hz}$ ) attached on it, 5 other traps had differently coloured (Red, Yellow, Green, Blue and White) Incandescent bulbs (JUNGSRAM 25W; G45, 220V, E27, 1000h) attached on it. The 2 traps remaining without bulbs served as control. The traps were arranged in a completely randomized design (CRD) in 6 replicates and ran simultaneously from $1800 \mathrm{hr}$ to $2400 \mathrm{hr}$ ( 6 hours). The light intensity for each bulb was measured in a dark room using a digital Lux meter (Serial no.: 20111100416). The intensities were; 60.2 lux, 243.2 lux, 513.8 lux, 736.8 lux and 351.2 lux for red, yellow, green, blue and white LED bulbs respectively, and 65.4 lux, 334 lux, 154.2 lux, 45.4 lux and 1094.2 lux, respectively for red, yellow, green, blue and white Incandescent bulbs. The bulbs were powered using a tiger generator (TG950). Collected insects were sorted and kept in a labelled universal container containing $70 \%$ ethanol by colour and bulb type. Samples of collected specimen were identified at the Insect Museum of Ahmadu Bello University, Zaria, Nigeria.

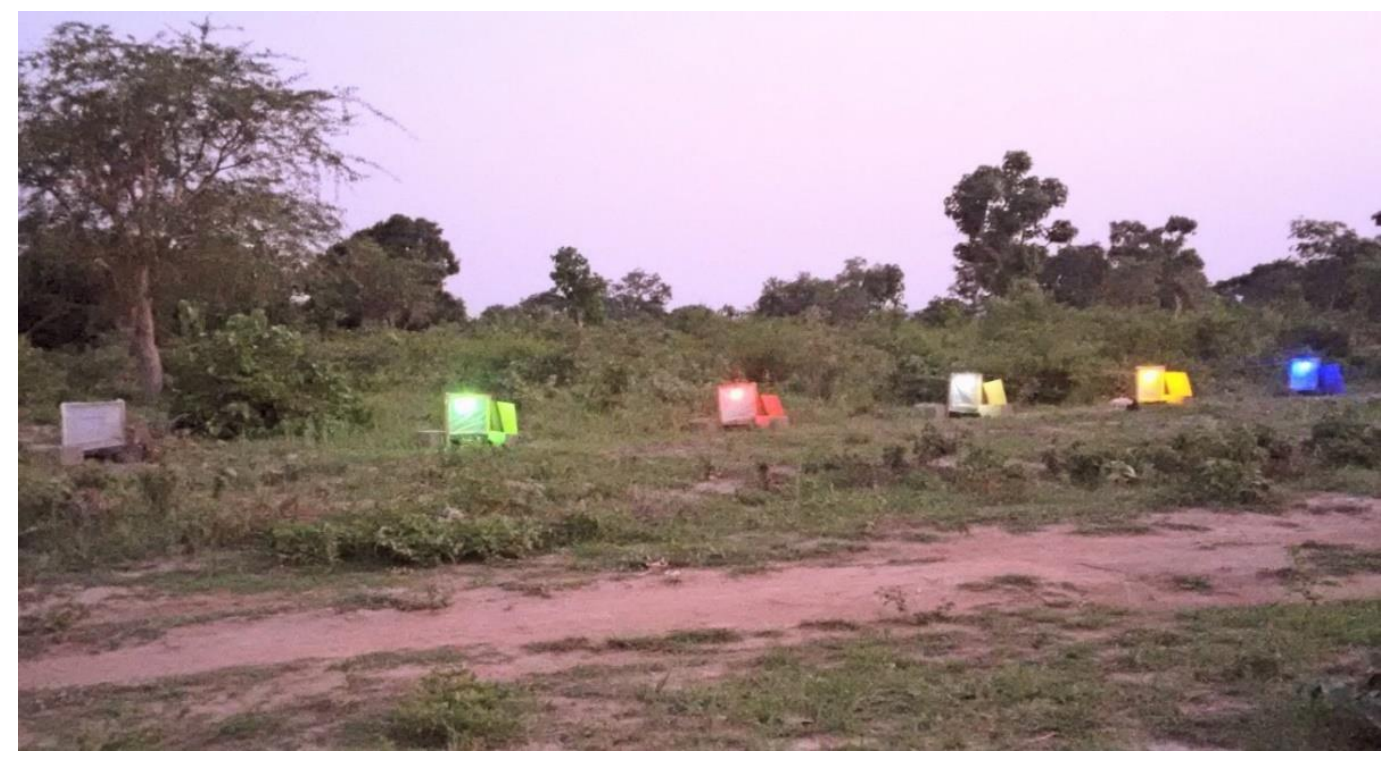

Figure 1: Fabricated light traps, spaced 3m apart used for sampling A. africana in the field

\subsection{Data analysis}

The data were normalized by transformation using $V_{x}+0.5$ before variance analysis. Significantly different treatment means was separated by Student Newman Keul's (SNK) test at $5 \%$ level of probability. Twotailed paired Student's t-test was used for comparing the attractiveness of LED and Incandescent bulb colours to $A$. africana. The relationship between light intensity of each bulb type and the density of $A$. africana attracted were determined by correlation and linear regression. All analysis was done using IBM SPSS Statistics version 23.0

\section{Results}

Among the LEDs, blue colour significantly $(\mathrm{p}=0.001)$ attracted the highest $(3.99 \pm 1.01)$ mean number of A. africana. Following are white and green colours with $3.11 \pm 0.58$ and $3.09 \pm 0.71$, respectively. The control attracted the least $(0.71 \pm 0.02)$ and was statistically comparable with yellow and red bulbs. Difference among A. africana attracted by incandescent bulb colours was significant $(\mathrm{p}<0.001)$ with white attracting the highest. Control and red attracted the least but were statistically at par with yellow, blue and green bulbs (Table 1). 
Flight to Light Response of Red Pumpkin Beetle (Aulacophora africana Weise)..................

Table1: Mean Number of A. africana Attracted by LED and Incandescent Bulb Colours

\begin{tabular}{|l|c|c|}
\hline Bulb colour & $\begin{array}{c}\text { Mean Number Attracted by } \\
\text { LED bulb }\end{array}$ & $\begin{array}{c}\text { Mean Number Attracted by } \\
\text { Incandescent bulb }\end{array}$ \\
\hline White & $3.11 \pm 0.58^{\mathrm{a}}$ & $4.30 \pm 0.38^{\mathrm{a}}$ \\
\hline Yellow & $1.90 \pm 0.43^{\mathrm{ab}}$ & $1.52 \pm 0.27^{\mathrm{b}}$ \\
\hline Blue & $3.99 \pm 1.01^{\mathrm{a}}$ & $0.86 \pm 0.15^{\mathrm{b}}$ \\
\hline Red & $0.78 \pm 0.03^{\mathrm{b}}$ & $0.71 \pm 0.01^{\mathrm{b}}$ \\
\hline Green & $3.09 \pm 0.71^{\mathrm{a}}$ & $1.02 \pm 0.31^{\mathrm{b}}$ \\
\hline Control & $0.71 \pm 0.02^{\mathrm{b}}$ & $0.71 \pm 0.02^{\mathrm{b}}$ \\
\hline F value & 5.49 & 5.24 \\
\hline P value & 0.001 & $<0.001$ \\
\hline
\end{tabular}

Mean $( \pm \mathrm{SE})$ followed by the same superscript letter(s) within a column are not significantly different using Student Newman Keul's test $(\mathrm{P} \leq 0.05)$

Table 2 reveals that, both individually and cumulatively; the LED bulb colours consistently attracted more A. africana than the incandescent bulbs except, on white. However, except for blue and green colours $(\mathrm{p}=$ $0.03)$, differences, between the bulb types were due to random variation ( $\mathrm{t} \alpha>0.05)$.

Table 2: Student's T-test Analysis on the Attractiveness of LED and Incandescent Bulb Colours to A. africana

\begin{tabular}{|l|c|c|c|c|c|}
\hline Bulb Colours & $\begin{array}{c}\text { Mean attraction } \\
\text { by LED bulb }\end{array}$ & $\begin{array}{c}\text { Mean attraction by } \\
\text { Incandescent bulb }\end{array}$ & $\begin{array}{c}\text { Mean } \\
\text { difference }\end{array}$ & T-value & $\begin{array}{c}\text { P-value } \\
(\text { to } \boldsymbol{)}\end{array}$ \\
\hline White & $3.11 \pm 0.58$ & $4.30 \pm 0.38$ & $-1.19 \pm 0.70$ & -1.71 & 0.12 \\
\hline Yellow & $1.90 \pm 0.43$ & $1.52 \pm 0.27$ & $0.38 \pm 0.50$ & 0.75 & 0.47 \\
\hline Blue & $3.99 \pm 1.01$ & $0.86 \pm 0.15$ & $3.14 \pm 1.02$ & 3.08 & 0.03 \\
\hline Red & $0.78 \pm 0.03$ & $0.71 \pm 0.01$ & $0.07 \pm 0.02$ & 0.04 & 0.97 \\
\hline Green & $3.09 \pm 0.71$ & $1.02 \pm 0.31$ & $2.07 \pm 0.78$ & 2.67 & 0.03 \\
\hline Grand Mean & $2.56 \pm 0.53$ & $1.68 \pm 0.14$ & $0.88 \pm 0.54$ & 1.62 & 0.16 \\
\hline
\end{tabular}

Table 3 shows a highly positive correlation between density of $A$. africana and bulb light intensity for both $\operatorname{LED}\left(\mathrm{p}=0.17, \mathrm{R}^{2}=51.7 \%\right)$ and Incandescent $\left(\mathrm{p}<0.001, \mathrm{R}^{2}=99.4 \%\right)$.

Table 3: Correlation and Linear Regression between A.africana count and Bulb Light Intensity

\begin{tabular}{|l|c|c|c|}
\hline Variables & $\begin{array}{c}\text { Correlation } \\
\text { coefficient (r) }\end{array}$ & $\begin{array}{c}\text { Regression } \\
\text { equation }\end{array}$ & $\begin{array}{c}\text { Coefficient of } \\
\text { determent }\left(\mathbf{R}^{2}\right)\end{array}$ \\
\hline $\begin{array}{l}\text { Mean Number of } A \text {. africana collected } \mathrm{x} \\
\text { LED bulbs intensity }\end{array}$ & $0.72^{\mathrm{ns}}$ & $\mathrm{Y}=1.563+0.03 \mathrm{x}$ & 0.517 \\
\hline $\begin{array}{l}\text { Mean Number of } A \text {. africana collected x } \\
\text { Incandescent bulbs intensity }\end{array}$ & $0.99^{* * *}$ & $\mathrm{Y}=0.529+0.03 \mathrm{x}$ & 0.994 \\
\hline
\end{tabular}

$* * *=$ significantly different $(\mathrm{P} \leq 0.01),{ }^{\mathrm{ns}}=$ not significantly different $(\mathrm{P}>0.05)$

\section{Discussion}

Light plays a vital part in insects' life by affecting their feeding behaviour, providing cue for predator avoidance, oviposition, navigation and mate selection [15]. Light has thus been used to manipulate or manage insect species for the benefit of man and the environment [6]. The differential attractiveness of different light colours and bulb types to different insect orders and families as observed in the present study which focused on $A$. africana have been documented [6], [16] and this have been useful in the management of the insect orders/families using light traps. Light traps using UV light have been reported to be very effective in insect sampling [8] but the high cost of UV lamps has led to its steady replacement by LEDs which have also be found to be effective and efficient in attractiveness to insects [14]. Owens [11] reported that blue coloured light is most attractive to insects. This view was supported by the findings of Hickel [9] which revealed that light wavelengths which are above $380 \mathrm{~nm}$ are more attractive to beetles. Our findings corroborated these as we observed that red pumpkin beetles are more attracted to blue and white LED bulbs. The high attractiveness of white LED bulb to red pumpkin beetle in present study can be attributed to its emission of radiations toward the blue region of light spectrum thereby providing a near-blue colouration which aligns with the region of maximum insect stimulation as reported by Owens [11]. 
Preference of insects to different light sources has been documented [16]-[17]. Antony [13] and Wakefield [16] reported that Incandescent bulbs were more attractive to insects than LED and compound fluorescent light sources due to the greater heat emitted by the Incandescent bulbs relative to the other bulb types. This contradicts the findings of Hickel [9] and Pawson [18] who reported LED bulbs to be a more attractive light source. The present study showed that though the overall difference in attractiveness of $A$. africana between LED and Incandescent bulbs was due to random variation, the LED bulbs were more attractive to red pumpkin beetles than Incandescent bulbs. Light intensity has been reported as a major contributing factor to insect attraction to light sources [11], [16]. Pawson [18] observed in their study that, higher light intensity of LED over Incandescent bulbs influenced higher attractiveness to insects. Also, Wakefield [16] who reported better attractiveness of Incandescent over LED bulbs attributed the finding to higher light intensity.

The LED bulbs used in present study had lower wattages (3W) as compared to its Incandescent counterpart which had $(25 \mathrm{~W})$. However, the LED bulbs overall, had higher mean light intensity than the Incandescent bulbs. Hence, the higher attractiveness of $A$. africana to LED bulbs than Incandescent bulbs could be attributed to higher intensity. Furthermore, among the Incandescent bulbs, white colour which had the highest mean attractiveness to $A$. africana in the present study also had the highest mean light intensity suggesting that higher light intensity results in higher attractiveness of insects. Different insect light traps have been developed over the years from light sources such as mercury vapour lamps, gas lamps and fluorescent UV light tubes predominantly for pest management purposes [19]. But LED technology is being steadily used to replace the afore-mentioned due to its efficiency, low energy consumption, lower cost, among others [14], [20]. Conventional light traps are relatively inexpensive and with minimal effort, light traps yield large number of insect specimen [19] and hence an effective, and eco-friendly means of pest management [9]. However, its major disadvantage is its limitation to nocturnal species and hence has limited effect on diurnal insect pests [19].

Although in the present study we made use of power plant in determining the response of red pumpkin beetle to the respective light sources, colours and/or intensities; lack of electricity distribution to cropping areas which was considered a major impediment to the use of light traps have been conquered with the invention of autonomous light traps using photovoltaic solar energy for powering the electronic systems [9] and, this solar power systems have been shown to be more efficient when incorporated with LED bulbs.

\section{Conclusion}

Nocturnal insects are sampled exclusively using light traps and knowledge of insect attractiveness to light colours and sources can be used for developing measures to safeguard the health of the crop production environment. The higher attractiveness of $A$. africana to blue LED and white Incandescent bulbs could be due to colour preference and/or higher light intensity of the bulbs. Hence, blue LED bulb or white Incandescent bulb of high light intensity could be incorporated into insecticidal lamps and used to suppress the population of $A$. africana either in green houses or open fields or the light bulb colours and types could also be incorporated into ordinary light traps and be used to harvest the insect for scientific research. But on solar powered light traps, blue coloured LED bulb is suggested to conserve power and enhance efficiency.

\section{Declarations}

\subsection{Acknowledgements}

Many thanks to Stephen Yakubu for his support during the field work and to Mr. Ishaku Musa of the Insect Museum of Ahmadu Bello University, Zaria, Nigeria for identifying the insect samples. Sincere appreciation also, to Mr. Adeniyi Ogunmola of the Department of Mathematics and Statistics, Federal University, Wukari, Nigeria for the statistical analyses. 


\subsection{Competing Interests}

The authors declare that no conflict of interest exist in this publication.

\section{How to Cite this Article}

C. Timothy, N. Samiala, and E. Okrikata, "Flight to Light Response of Red Pumpkin Beetle (Aulacophora africana Weise) to Differently Coloured Light-emitting Diode and Incandescent Bulb Lights”, Adv. J. Grad. Res., vol. 7, no. 1, pp. 64-69, Nov. 2019. doi:10.21467/ajgr.7.1.64-69

\section{References}

[1] A. Barroso, I. Haifig, V, Janei, I, da Silva, C, Dietrich and A.M. Costa-Leonardo, "Effects of flickering light on the attraction of nocturnal insects," Lighting Research Technology, vol. 49, no. 1, pp. 1-11, Aug. 2015.

[2] M.A. Rashid, M.A. Khan, M.J. Arif and N. Javed, "Red pumpkin beetle, Aulacophora foveicollis Lucas: a review of host susceptibility and management practices," Academic Journal of Entomology, vol. 7, no. 1, pp. 38-54, Jan. 2014.

[3] K. Hassan, M.M. Uddin and M.A. Haque, "Host suitability of red pumpkin beetle, Aulacophora foveicollis (Lucas) among different cucurbitaceous hosts," IRJALS Research Paper, vol. 1, no. 4, pp. 91-100, Sept. 2012.

[4] B.D. Datinon, A.I. Glitho, M. Tamò, K. Amevoin, G. Goergen and O.K.D. Kpindou, "Inventory of major insects of Jatropha curcas L. (Euphorbiaceae) and their natural enemies in southern Benin," ARPN Journal of Agricultural and Biological Science, vol. 8, no. 10, pp.711-718, Oct. 2013.

[5] T. Bidein, N.E.S. Lale and U. Zakka, "Efficacy of combining varietal resistance with organic fertilizer application in reducing infestation of cucumber (Cucumis sativus L.) by insect pests in the Niger Delta," International Journal of Health and Psychology Research, vol. 5, no. 3, pp. 22-36, Oct. 2017.

[6] S. Thangalakshmi and R. Ramanujan, "Electronic trapping and monitoring of insect pests troubling agricultural fields," International Journal of Emerging Engineering Research and Technology, Vol. 3, no. 8, pp. 206-213, Aug. 2015.

[7] A. Nirmal, K.G. Rupesh, K.S. Yogesh and L.G. Jaya, "Evaluation of light trap against different coloured electric bulbs for trapping phototrophic insects," International Journal of Microbiology for Applied Sciences, vol. 6, part 6, pp. 2068-2073, Jun. 2017.

[8] J.A. Hogsette, "Turning ultraviolet light traps on and off increases their attraction to house flies (Diptera: Muscidae)," Journal of Insect Science, vol. 19, no. 1, pp. 1-3, Jan. 2019.

[9] E.R. Hickel, G.C. Knabben, D.D. Zotto, M.W.M. Carvalho, B. Bertoldi and Y.R. Novaes, "Attractiveness of light-emitting diodes (LEDs) of different wavelengths to the South American rice water weevil," Arquivos do Instito Biologico, vol. 85, pp. 1-6, 2018.

[10] K. Shibuya, S. Onodera and M. Hori, "Toxic wavelength of blue light changes as insects grow," PLoS ONE, vol. 13, no. 6, pp. e0199266, Jun. 2018.

[11] A.C.S. Owens and S.M. Lewis, "The impact of artificial light at night on nocturnal insects: a review and synthesis," Ecology and Evolution, vol. 8, pp. 11337-11358, Jul. 2018.

[12] L.M. Botha, T. M. Jones and G.R. Hopkins, "Effects of lifetime exposure to artificial light at night on cricket (Teleogryllus commodus) courtship and mating behaviour," Animal Behaviour, vol. 129, pp. 181-188, 2017.

[13] J.M. Antony and A.P. Sebastian, "Comparative study on nocturnal insects attracted to various light sources," Imperial Journal of Interdisciplinary Research, vol. 2, no. 7, pp. 1559-1561, 2016.

[14] B.A.S. de Medeiros, A. Barghini and S.A. Vanin, "Streetlights attract a broad array of beetle species," Revista Brasileira de Entomologia, vol. 61, pp. 74-79, Dec. 2017.

[15] J.Q. Ouyang, S. Davies and D. Dominoni, "Hormonally mediated effects of artificial light at night on behavior and fitness: linking endocrine mechanisms with function," Journal of Experimental Biology, vol. 221, no. 6, pii. jeb156893, Mar. 2018.

[16] A. Wakefield, B. Moth, L.S. Emma, J. Gareth and H. Stephen, "Quantifying the attractiveness of broad- spectrum street lights to aerial nocturnal insects," Journal of Applied Ecology, vol. 55, pp. 714-722, Aug. 2017.

[17] T. Longcore, A. Rodríguez, B. Witherington, J.F. Penniman, L. Herf and M. Herf, "Rapid assessment of lamp spectrum to quantify ecological effects of light at night," Journal of Experimental Zoology, vol. 1, pp. 1-11, Jun. 2018.

[18] S.M. Pawson and M.K.F. Bader, "LED lighting increases the ecological impact of light pollution irrespective of color temperature," Ecological Applications, vol. 24, part 7, pp. 1561-1568, Oct. 2014.

[19] A.H. Sheikh, M. Thomas, R. Bhandari and K. Bunker, "Light traps and insect sampling: an overview," International Journal of Current Research, vol. 8, no. 11, pp. 40868-40873, Nov. 2016.

[20] S. Bae, J.O. Park, B. Mainali, H. Kim, Y. Yoon, Y. Lee and Y. Cho, "Evaluation of different light colors in solar trap as attractants to cereal and legume insect pests," Korean Journal of International Agriculture, vol. 27, no. 4, pp. 516-521, Nov. 2015.

Publish your books with AIJR publisher-

$\checkmark$ Publish with ISBN and DOI.

$\checkmark$ Publish Thesis/Dissertation as Monograph.

$\checkmark$ Publish Book Monograph.

$\checkmark$ Publish Edited Volume/ Book.

$\checkmark$ Publish Conference Proceedings

$\checkmark$ Retain full copyright of your books.

Submit your manuscript at books.aijr.org
Publish your research article in AIJR journals-

$\checkmark$ Online Submission and Tracking

$\checkmark$ Peer-Reviewed

$\checkmark$ Rapid decision

$\checkmark \quad$ Immediate Publication after acceptance

$\checkmark$ Articles freely available online

$\checkmark$ Retain full copyright of your article.

Submit your article at journals.aijr.in 